\title{
THE PAS DE DEUX BETWEEN EDUCATION AND RECREATION: FACILITATING THE REALISATION OF ARTICLES 11 AND 12 OF THE AFRICAN CHARTER ON THE RIGHTS AND WELFARE OF THE CHILD IN SCHOOLS
}

\author{
by Thandeka N. Khoza* \& Cebolenkosi Zuma**
}
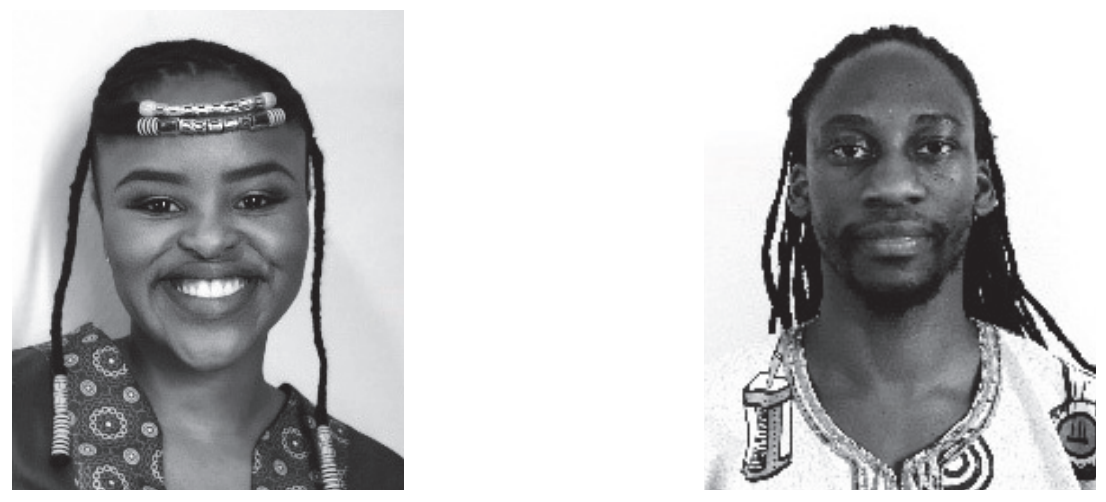

\section{Introduction}

The African Charter on the Rights and Welfare of the Child (African Children's Charter) is the regional instrument which protects children's rights in Africa. ${ }^{1}$ Having been adopted in $1990,{ }^{2}$ this year is

* Doctoral Candidate and Researcher in the Children's Rights Project at the Dullah Omar Institute, University of the Western Cape. She holds a BA(Law), LLB and LLM(Human Rights and Democratisation in Africa) from the University of Pretoria and a Diploma (Justiciability of ESCR) from Abo Akademi University. Email: tkhoza@uwc.ac.za. ORCID: 0000-0001-6107-5290.

** Performing artist, scholar, movement facilitator, and Choreographer. He holds a Diploma in Dance Education and a Postgraduate Certificate in Education (Dance Studies FET) from the University of Cape Town. He has been accepted for an MA in Dance Movement Psychotherapy at Goldsmiths, University of London. He is also the Co-Founder of Kwasukasukela Arts Collective. Email: zmxcebo001@ myuct.ac.za. ORCID: 0000-0002-8864-8113.

1 D Olowu 'Protecting Children's Rights in Africa: A critique of the African Charter on the Rights and Welfare of the Child' (2002) 10 The International Journal of Children's Rights 127.

2 Olowu (n 1 above) $127 \& 134$. 
momentous as the Charter celebrates 30 years since entry into force. ${ }^{3}$ This anniversary brings with it a unique and important opportunity to reflect on what has been achieved since the adoption of the Charter in 1990, as well as assess what may still need to be achieved going forward. This anniversary is also especially opportune in that it coincides with the five-year anniversary of the United Nations' Sustainable Development Goals. ${ }^{4}$ Therefore, in light of future development, this anniversary allows us to investigate how the African Children's Charter can still assist State Parties in achieving the realisation of children's rights in an everchanging and constantly developing world.

- The African Children's Charter is a landmark treaty in the arena of children's rights. This is because the then Organisation for African Unity, now African Union, was the first regional body to promulgate a regional instrument focusing on the rights and protection of children. ${ }^{5}$ The African Children's Charter has also been lauded as being more sophisticated in its protection of children's rights, ${ }^{6}$ especially within the African continent. ${ }^{7}$ One of the most common reasons for this praise is the fact that the Charter contemplates child rights issues which are not reflected in the United Nations Convention on the Rights of the Child (CRC), but are specific to African children. ${ }^{8}$ The African Children's Charter was drafted, in part, because the CRC 'does not contemplate the socio-cultural realities of the African experience'. ${ }^{9}$ Because of the Convention's blindness to the cultural context and realities of African children, then, the African Children's Charter was developed to complement and supplement the Convention where it was blind. ${ }^{10}$ The drafting of the African Children's Charter, thus, was necessitated by the deficiencies of $\operatorname{th}^{11} \mathrm{e}$ CRC.

- Of relevance to this article is a consideration of the manner in which the African Children's Charter contemplates and advances the rights

3 The African Charter on the Rights and Welfare of the Child (African Children's Charter) was adopted at the twenty-sixth Ordinary Session of the Assembly of Heads of State and Government of the OAU in Addis Ababa (11 July 1990); A Lloyd 'A theoretical analysis of the reality of children's rights in Africa: An introduction to the African Charter on the Rights and Welfare of the Child' (2002) 2(1) African Human Rights Law Journal 11.

4 United Nations General Assembly Transforming our world: the 2030 Agenda for Sustainable Development (21 October 2015) A/RES/70/1.

$5 \quad$ Lloyd (n 3 above) 13.

$6 \quad$ Lloyd (n 3 above) 14 - 15; D Olowu (n 1 above) 130.

7 Olowu (n 1 above) 128.

8 F Viljoen 'Supra-national human rights instruments for the protection of children in Africa: The Convention on the Rights of the Child and the African Charter on the Rights and Welfare of the Child (1998) 31 Comparative and International Law Journal of Southern Africa 205.

9 Olowu (n 1 above) 128.

10 LM Kohm 'A brief assessment of the 25-year effect of the Convention on the Rights of the Child' (2015) 23(323) Cardozo Journal of International Comparative Law 324.

11 M Nyarko \& H Ekefre 'Recent Advances in Children's Rights in the African Human Rights System' (2016) 15 The Law and Practice of International Courts and Tribunals. 
to education and recreational activity. ${ }^{12}$ Especially recalling the added value of the African Children's Charter in terms of the protection of African children's rights, ${ }^{13}$ this paper focuses on two particular rights protected by the African Children's Charter: the right to education and the right to recreational activity. The argument which will be advanced in this article is that African children would benefit from accessing schools which offer them an education infused with recreational activity, through the creation of space and time for recreational activity within the school day. To this end, it will be suggested that crafting curricula which include recreational activity, specifically in the form of dance, will assist to improve the quality of education available to African children. It is argued that this proposed curriculum is a move towards the provision of the quality education demanded by the African Committee of Experts on the Rights and Welfare of the Child (ACERWC) in its Agenda 2040 for Children's Rights in Africa (Agenda 2040). ${ }^{14}$ In order to do this, this article will first explore the content of article 11, which relates to the right to education. Thereafter, it will move to unpack the meaning of article 12 , which deals with the right to recreational activity, as well as its implications. This article will then give a short account of the links between these provisions, within the context of the best interests of the child. Finally, the paper will conclude with a summary of its formulation, particularly within the context of Agenda 2040.

\section{Article 11 of the African Charter on the Rights and Welfare of the Child: The Right to Education}

As a point of departure, the direction of this article, and the arguments made herein, necessitate a contextualisation of the protection of the right to education. The right to education has been recognised since $1948 ;{ }^{15}$ however, it was later contemplated specifically as it relates to children in $1989 .{ }^{16}$ The United Nations Committee on the Rights of the Child (UNCRC) has also outlined the aims of education and what they mean in terms of state party obligations. ${ }^{17}$ The UNCRC has written that all the elements relating to the aims of education are geared towards children's rights, including their rights to the holistic development of their full potential, an

12 Olowu (n 1 above) 130.

13 Olowu (n 1 above); Lloyd (n 3 above) 13.

14 African Committee of Experts on the Rights and Welfare of the Child (ACERWC) Africa's Agenda for Children 2040: Fostering an Africa Fit for Children (Agenda 2040) (November 2016) Aspiration Six.

15 The first instrument to codify the right to education was the Universal of Human Rights at art 26.

16 The first instrument to protect the child's right to education was the Convention on the rights of the Child at arts $28-29$.

17 United Nations Committee on the Rights of the Child (UNCRC) General Comment No 1 (2001) Article 29(1): The Aims of Education CRC/C/GC/2001/1. 
enhanced sense of identity and affiliation as well as socialisation and interaction with others. ${ }^{18}$ These themes are contemplated in the arguments made later in the paper which are in favour of recreational activity in schools.

Although the content of the right to basic education has not received as much attention as access to education, the UNCRC has categorically declared that the right to education includes both elements of access as well as content. ${ }^{19}$ The Committee has also stated that the provisions of article 29 of the Convention offer a 'qualitative dimension' to the right to education through insisting that children's education should be child-centred, child-friendly and empowering. ${ }^{20}$ Furthermore, all children are entitled to an education which will develop their relevant skills, abilities, learning and other capacities, their dignity, self-confidence and talents. ${ }^{21}$

By virtue of the amount of time for which the right has been recognised by international law, then, major developments over the years were also bound to have taken place. Of particular importance was the development of the 'Four-A-Scheme', a fairly recent development, ${ }^{22}$ which was adopted by the United Nations Committee on Economic, Social and Cultural Rights (Committee on ESCR). ${ }^{23}$ In terms of the Four-A-Scheme, there are four elements to the right to education, namely availability; ${ }^{24}$ accessibility; ${ }^{25}$ acceptability; ${ }^{26}$ and adaptability. ${ }^{27}$ These four features, which education in all states, regardless of economic or other standing, must exhibit, are a useful foundation from which we can begin to interpret and ascribe substance to the right to education. ${ }^{28}$

Within the context of this particular article, it is important to unpack the right to education as it is contemplated in the African Children's Charter. It is worth noting that, for the most part, the African Children's Charter offers a protection of the right to education which is similar to the type of protection found or offered within the CRC. ${ }^{29}$ However, it is just as important to mention that, in

UNCRC General Comment No 1 para 1.

UNCRC General Comment No 1 para 3.

UNCRC General Comment No 1 para 2.

21 As above.

22 The 'Four A Scheme' was developed in 2006 by the late Katarina Tomasevski, who was the first United Nations Special Rapporteur on the Right to Education. See K Tomasevski Human Rights Obligations in Education: The 4-A Scheme (2006).

23 United Nations Committee on Economic, Social and Cultural Rights (Committee on ESCR) General Comment No 13: The Right to Education (Art 13) (1999) E/C.12/ 1999/10 (General Comment No 13) para 6(a - d).

24 Committee on ESCR General Comment No 13 para 6(a).

25 Committee on ESCR General Comment No 13 para 6(b).

26 Committee on ESCR General Comment No 13 para 6(c).

27 Committee on ESCR General Comment No 13 para 6(d).

28 F Veriava Realising the Right to Basic Education: The Role of the Courts and civil Society (2019) 8 - 9.

29 M GoseThe African Charter on the Rights and Welfare of the Child (2002) 112. 
some areas, the African Children's Charter contemplates issues which are not found within or protected by the CRC. ${ }^{30}$ For example, the African Children's Charter contains within one article the contents of the right to education as well as the aims and purposes of education, ${ }^{31}$ whereas the CRC divides the two themes between two separate articles. ${ }^{32}$ Another difference between the African Children's Charter and the CRC is that the African Children's Charter introduces a provision which obligates State Parties to implement affirmative action measures in favour of disadvantaged, female and gifted children in their provision of access education. ${ }^{33}$ The African Children's Charter also contemplates the themes of preservation of national independence, ${ }^{34}$ territorial integrity, ${ }^{35}$ and African unity and solidarity within education. ${ }^{36}$ Added values notwithstanding, however, the provisions of the African Children's Charter which are of particular importance for this section of the paper are reflected within sub-articles (1) as well as (3)(a), (b) and (d). Article 11(2)(a) will be discussed at the end of this section of the article because it links to the discussion of article 12 , which will follow in the next section.

The African Children's Charter guarantees the right to an education for every African child. ${ }^{37}$ Simply stated, this means that every State Party has an obligation to ensure that every child within its territory has access to education. On the subject of State Parties, it is worth noting that the African Children's Charter enjoys nearuniversal ratification on the continent, with only one reservation to the education provisions. ${ }^{38}$ Therefore, positively, this paper has a large portion of the continent as its audience. Having noted this, of course, it is important to highlight that the African Children's Charter goes into further detail by way of compartmentalising the right and assigning different outcomes as well as levels and types of obligations in relation to the right.

30 Kohm (n 10 above) 324; Nyarko \& Ekefre (n 11 above).

31 Both the content and aims of (the right to) education are encapsulated in article 11 of the African Children's Charter.

32 The contents of the right to education within the Convention on the Rights of the Child are found in article 28 and the aims of education are found in article 29.

33 African Children's Charter art 11(3)(e).

34 African Children's Charter art 11(2)(e).

35 African Children's Charter art 11(2)(f).

36 African Children's Charter art 11(2)(h).

37 African Children's Charter art 11(1).

38 The African Children's Charter enjoys the ratification of 49 of the 55 African States. The states which have not ratified the Charter yet are the Democratic Republic of Congo, Morocco, Sahrawi Arab Democratic Republic, Somalia, South Sudan and Tunisia. Of the ratifying States, Botswana, Egypt, Mauritania and Sudan have reservations to varying provisions, with Sudan having a reservation to article 11(6). This information is available at https://www.acerwc.africa/ratificationstable/ (accessed 22 April 2020). 
It is in sub-article three that the African Children's Charter maps out the different types of obligations which State Parties have in relation to the different levels of schooling. The Charter provides that: ${ }^{39}$

State Parties to the present Charter shall take all appropriate measures with a view to achieving the full realisation of [the right to education] and shall in particular:

(a) provide free and compulsory basic education;

(b) encourage the development of secondary education in its different forms and to progressively make it free and accessible to all;

(c) make higher education accessible to all on the basis of capacity and ability by every appropriate means;

(d) take measures to encourage regular attendance as schools and the reduction of dropout rates;

(e) take special measures in respect of female, gifted and disadvantaged children, to ensure equal access to education for all sections of the community.

Most relevant to the discussion in this article are items (a), (b) and (d). ${ }^{40}$ With specific regard to basic education, ${ }^{41}$ in terms of the Charter, State Parties are obligated to make basic education both free as well as compulsory. ${ }^{42} \mathrm{~A}$ simple reading of this provision reveals that its aim is to equip children with the basic tools of literacy, numeracy and other learning areas, so that they may be able to progress both in education and in life. ${ }^{43}$ It is worth noting here, with reference to the World Declaration on Education for All, 44 that 'basic education' actually refers to the content of education - which also includes skills relating to oral expression and problem-solving. ${ }^{45}$ In addition to the content of the right, the fact that the basic level of education must be free and compulsory also speaks to the fact that State Parties have a duty to ensure universal access to education for all children within their states. ${ }^{46}$ It is also argued that, while secondary education should be 'progressively' made free and accessible to all children, ${ }^{47}$ this provision is not a means to evade any obligation to provide for this

39 African Children's Charter art 11(3)(a - e).

40 African Children's Charter art 11(3)(a),(b) \& (d).

41 It is interesting to note that, unlike the United Nations instruments, including the CRC and the ICESCR, the African Children's Charter speaks of free and compulsory 'basic' education, not 'primary' education. However, despite this semantic difference, the provisions seem to offer the same protection.

42 African Children's Charter art 11(3)(a).

43 TN Khoza 'The End Justifies the Means: Realising the Right to Education for the Girl Child as a Means to Achieving Economic Growth and Empowerment in Africa' in MN Amutabi Africa's New Deal (2019) 235.

44 United Nations Educational, Scientific and Cultural Organisation (UNESCO) World Declaration on Education for All (1990).

45 LN Murungi 'Inclusive basic education in South Africa: Issues in its conceptualization and implementation' (2015) 18(1) Potchefstroom Electronic Law Journal 3161.

46 Lloyd (n 3 above) 13.

47 African Children's Charter art 11(3)(b). 
level of education. Rather, as the Committee on ESCR has noted, ${ }^{48}$ the 'progressive realisation' of socioeconomic rights does not allow for the non-realisation or a deliberate delay in the realisation of socioeconomic rights. ${ }^{49}$ Instead, this term should be read so as to mean that State Parties should do all they can to ensure that the minimum core of any socioeconomic right is ensured, with the vision of always improving access to and the quality of the right. ${ }^{50}$ Therefore, if we take basic education to be synonymous with primary education, which is often the case, ${ }^{51}$ it is argued here that the protection of the right to basic education goes hand in hand with the protection of the right to secondary education. State Parties cannot ensure basic education without also making plans to ensure that children who have passed the basic levels of education are able to progress to the secondary level of schooling. Basic education is, and should be seen as, a means to an end; not just an end in and of itself. Education is both an ends and a means because it is a basic human right and developmental goal in its own right as well as a gateway right the realisation of which assists in the further realisation of other rights, such as improved health, personal growth and development. ${ }^{52}$

The final education-related provision of the African Children's Charter which is of great relevance in this article is the obligation which State Parties have to make every effort to retain children in school and decrease dropout rates. ${ }^{53}$ This provision was a well thought inclusion on the part of the drafters, especially because it is directly linked to and reiterates the notion of access to education and the interconnectedness of all the levels of schooling. Moreover, although it was drafted over three decades ago, it is still relevant because there is still no universal access to education, and countries are not on track to achieving universal access within the next decade either. ${ }^{54}$ Access to education alone is not enough; children should be able to retain the information which they are taught, ${ }^{55}$ and schools should in turn be able to retain children, through their progression through the different grades and levels of their schooling career. ${ }^{56}$

Noting the obligation placed upon State Parties to retain children within schools, it is argued in this article that the inclusion of 'General Comment No 3: The Nature of State Parties' Obligations (Art.2, Para.1, of the Convention)' E/1991/23 (11 July 1990).

49 Committee on ESCR General Comment No 3 paras 9 - 10.

50 Committee on ESCR General Comment No 3 para 10.

51 Murungi (n 45 above) 3161.

52 A Szirmai 'Education and Development' in A Szirmai Socio-Economic Development $2^{\text {nd }}$ Edition (2015) 237.

53 African Children's Charter art 11(3)(d).

54 UNESCO ‘Global Education Meeting 2018: Brussels Declaration’ (2018) para 1.

55 Whitehead (n 43 above) 197; Lloyd (n 3 above) 19.

56 UNESCO 'Incheon Declaration and Framework for Action for the Implementation of Sustainable Development Goal 4' (2016) ED-2016/WS/28, 31 para 18. 
recreational activity in the school curriculum has the potential to assist in retaining children in school. By adding a fun and active subject to the curriculum, this gives children another reason to look forward to and remain in school. Not only that, recreational activities can also be used to assist children to understand school content better, as children have different learning capabilities and styles. Because the education accessed by children must be of good quality, ${ }^{57}$ this means that the curricula which are set by ministries of education should also pay heed to children and their different abilities to process the work they are taught. Remaining cognisant of this will also allow ministries of education and teachers to investigate and implement possible aids for better performance. This also means that state curricula should be as diverse as practically possible, thereby offering children with a wider range of opportunities after school.

The benefits of recreational activity for children at school will be detailed below. However, what is important to note at this juncture is the argument that making recreational activity part of the school curricula will assist State Parties to fulfil two obligations simultaneously. Through offering recreational activity at schools, the State Parties will be fulfilling their obligations in terms of article 11 and article 12 of the Charter. Therefore, this school-setting pas de deux approach to the realisation of these two rights is both favourable and beneficial.

On the subject of the pas de deux between these two provisions, which protect the right to education and the right to recreation, it is important to now refer to sub-article two of the Charter's education provision, which states that: ${ }^{58}$

The education of the child shall be directed to [...] the promotion of the child's personality, talents and mental and physical abilities to their full potential (own emphasis added).

Building on the requirement for universal access to education for African children, ${ }^{59}$ it is argued that the African Children's Charter then places a premium on recreational activity within the syllabus by requiring the education provided to children to also be aimed at improving their mental and physical development. ${ }^{60}$ Because of the wording of sub-article (2)(a), it is argued that the African Children's Charter does indeed support, perhaps it even requires, the implementation of a curriculum which includes recreational activity.

57 ACERWC Agenda 2040 Aspiration 6.

58 African Children's Charter art (11)(2)(a).

59 African Children's Charter art 11(1).

60 African Children's Charter art 11(2)(a). 
It admits of no debate that recreational activity contributes positively to both mental as well as physical development. ${ }^{61}$

Oftentimes, when recreational activity forms part of a curriculum, it does so as part of the subject 'physical education'. Regrettably, recreational activities syllabi, such as physical education, are often undervalued and viewed as being less important than other subjects in a number of schools globally. ${ }^{62}$ When compared to other subjects, physical education is often viewed as a waste of time and its academic value is largely overlooked; as a result of this, it is often marginalised to make way for what are viewed as 'more valuable' subjects ${ }^{63}$. This is not a surprising state of events which also supports this claim, of physical education being marginalised, because a number of schools do not include physical education syllabi within their school curricula.

While there are a number of different recreational and physical activities which can form part of a curriculum, in the form of physical education, as stated at the beginning of the paper, this article focuses specifically on the activity of dance. It should be borne in the mind that physical activities, such as childhood games, which often have an element of dance, for example, can aid a child's holistic development. ${ }^{64}$ Dance can be considered another form of physical education, as it shares the same abilities of fostering the physical, moral, social, emotional, cultural, and intellectual development of children. ${ }^{65}$ Dance does differ from conventional forms of physical education in its ability to nurture artistic and cultural expression which have long been a part of the cultural fabric of Africa. 'Historically, cultural [heritage] music and dances have been key to the day-to-day life of African people ... in different communities dances embody and exude complex meanings relating to the experiences of the people. ${ }^{, 66}$

In essence, dance education contributes to the child's cognitive development; physical development; socio-emotional development as well as cultural development. This article will address each of these

61 UNCRC General Comment No 17 (2013) on the right of the child to rest; leisure; play; recreational activities; cultural life and the arts (Art 31) CRC/C/GC/17 paras 8 - 9; A Watt et al 'Physical Education' in T McKenna (Ed) Engaging the Disengaged: Inclusive Approaches to Teaching the Least Advantaged (2013) 110.

62 CS Zuma 'Utilizing Indigenous Pedagogy of South African childhood games, and song in the dance classroom with secondary students' PGCE dissertation, UCT, 2019 at 6 (unpublished).

63 A Sprake \& C Palmer 'The Conversation' 2018 https://theconversation.com/ physical-education-is-just-as-important-as-any-other-school-subject-103187 (accessed 25 April 2020).

64 CS Zuma (n 62 above) at 8

65 Sprake \& Palmer (n 63 above).

66 AMB Mabingo 'Deconstructing pedagogies of African cultural heritage dances: Reflections, rationalities, and practices of dance teachers in central Uganda' unpublished PhD thesis, University of Auckland, 2018 at 22. 
themes individually and in more detail following the discussion on Article 12 on the African Children's Charter

\section{Article 12 of the African Charter on the Rights and Welfare of the Child: The Right to Leisure; Recreation and Cultural Activities}

Having mapped out the right to education and its importance, this paper now turns its focus to the second part, which unpacks the right to recreational activity. In terms of the African Children's Charter, State Parties are obligated to recognise that every child has a right to 'rest and leisure, to engage in play and recreational activities appropriate to the age of the child and to participate freely in cultural life and arts. ${ }^{, 67}$ This provision is heavy laden with different aspects of activity, each one carrying unique and different yet interconnected obligations. However, the focus for this paper will be on the aspect of recreational activity.

The argument advanced in this article is that the right to education and the right recreational activity, while they exist as independent rights, are also rights the realisation of which are a precondition for the realisation of a child's right to development to his or her full potential. ${ }^{68}$ This argument is also in line with the general belief that human rights are interconnected and interdependent. ${ }^{69}$

In support of the proposed pas de deux curricula approach, it has been argued that the right to education is not only about the attainment of literacy, but also about artistic skills; understanding one's social environment and the development of personal skills. ${ }^{70}$ Scholastic recreational activities, as a part of or in the form of physical education, offer an opportunity for learners to receive critical information which in turn facilitates the learners' understanding of lifestyle choices and ongoing positive development of their physical and psychological wellbeing. ${ }^{71}$ Physical education must also be multifaceted and include elements of creative movement, fitness, activities and the learners' physical and psychological health; social interactions as well as cognitive performance. ${ }^{72}$ Dance is one such a physical and recreational

67 African Children's Charter art 12(1).

68 Committee on ESCR General Comment No 13 para 1.

69 Global Citizenship Commission 'The Universal Declaration of Human Rights in the $21^{\text {st }}$ Century: A Living Document in a Changing World' (2016) 18.

70 A Szirmai 'Education and Development' in A Szirmai (n 52 above) 265.

71 A Watt et al 'Physical Education' in Marcelle Cacciattolo et al Engaging the Disengaged: Inclusive Approaches to Teaching the Least Advantaged (2013) 110.

72 Watt et al (n 71 above) 116. 
activity. ${ }^{73}$ Dance is also an especially beneficial form of recreational activity because it is both recreational as well as artistic. Therefore, offering learners a space and time in which they can dance is the creation of opportunities to be active, boost their confidence and make them more engaged; empathic and aware students. ${ }^{74}$

The World Health Organisation (WHO) has also enumerated a number of benefits of physical activity. WHO defined physical activity to include play, games, sport, recreation, physical education and planned exercise; furthermore, it recommended at least 60 minutes a day of age-appropriate physical activity for children. ${ }^{75}$ It is worth mentioning at this juncture that, because of the amount of time children spend at school, working recreational activities into their school life will be an effective way to ensure that they have the time and space to perform and learn from recreation. WHO has listed physical health benefits, such as the development of healthy and well-functioning bodies, psychological benefits, such as the improvement of control in situations of anxiety and the benefits of social development, through opportunities of self-expression, social interaction and building confidence. ${ }^{76}$

The UNCRC has also stated that one of the aims of education is to build the self-esteem, capabilities and confidence ${ }^{77}$ - all of which can be achieved through dance education. The right to education is also linked to the rights to freedom of expression and development, ${ }^{78}$ which are also facilitated through dance education. Access to and content of education for children must also be child centred, so that it focuses on the development of the child's creative talents, interests and other tools which the child may use immediately and later in life. ${ }^{79}$ As will be shown below, this is also an achievable goal of dance education.

The UNCRC has also noted, with concern, the poor investment into and implementation of the child's right to recreational activity, and other connected and similar rights. ${ }^{80}$ The realisation of the right to recreational activity is important because, in addition to enriching a child's life, it is fundamental to the child's optimum development, creatively and physically. ${ }^{81}$ It was also emphasised by the UNCRC that

73 Watt et al (n 73 above) 118.

74 T McKenna et al 'Arts Education: Do the arts really matter?' in T McKenna et al Engaging the Disengaged: Inclusive Approaches to Teaching the Least Advantaged (2013) $74-80$.

75 World Health Organisation 'Global Recommendations on Physical Activity for Health 5 - 17 years old (2011) https://www.who.int/dietphysicalactivity/ publications/physical-activity-recommendations-5-17years.pdf?ua=1.

76 World Health Organisation (n 75 above).

77 UNCRC General Comment No 1 para 2.

78 UNCRC General Comment No 1 para 6.

79 UNCRC General Comment No 1 para 9.

80 UNCRC General Comment No 17 para 2

81 UNCRC General Comment No 17 para 8. 
recreational activity is also essential to the health and wellbeing of the child as well as promotes the development of creativity, imagination and physical, cognitive and strength skills. ${ }^{82}$ Therefore, the positive value of recreational activity to the child's development needs to be recognised. 83

An Africa fit for children, as envisaged in Agenda 2040, ${ }^{84}$ can only be an Africa in which every child is exposed to as many opportunities as possible. Some key opportunities to which all children are entitled include opportunities to be healthy, ${ }^{85}$ to grow, ${ }^{86}$ to develop mentally, ${ }^{87}$ to develop physically, ${ }^{88}$ to progress in education, ${ }^{89}$ and to also contribute to and benefit from the development of their nations. ${ }^{90}$ The pas de deux curricula approach allows for education to be directed towards the full development of the child's abilities to their full potential. The implementation of recreational activity at schools, then, is essential for the achieving compliance with the right to education provisions, both in the African Children's Charter as well as Agenda $2040 .^{91}$

It is also argued in this article that adding recreational activity to school curricula, specifically dance, as will be argued for in the following section, will not place a strenuous burden on State Parties in terms of the provisioning which must take place in order to actualise the right in schools. For example, by drawing on the rich cultures of their peoples, State Parties can include dances which are already part of the different communities in the curricula. Essentially, then, in terms of practical steps which must be taken in order to realise this right in schools, beyond drafting and passing legislation and policies, State Parties will have to mandate schools to ensure that the school day includes a dedicated time slot for recreational activity.

\section{$4 \quad$ Unpacking the benefits quadrigeminal of recreational activity for children through the lens of dance education}

Having established that there is a protection of the right to physical education within the African Children's Charter, this article will now

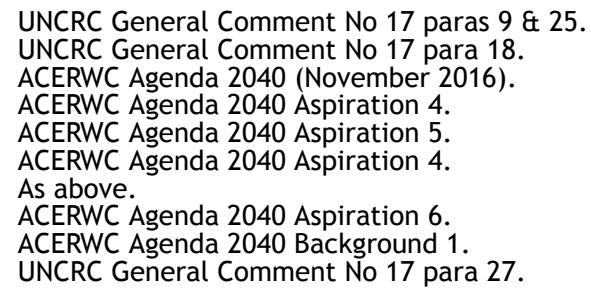


take a look at the approach of South Africa's Curriculum and Assessment Policy Statement (CAPS) for Dance Studies for Grades 10 to 12 , as amended by the Department of Basic Education. ${ }^{92}$ Of particular interest here is how the document uses the daily dance practice and dance theory aims in order to promote 'fitness and a healthy lifestyle and [equip] learners with crucial life skills, such as self-discipline, creativity, critical thinking, leadership and teamwork, all of which will benefit them in any field of interest'. ${ }^{93}$ As a State Party to the African Children's Charter and as a state which has a dance syllabus as part of the school curriculum, it is helpful to look at the provisions within South African policy so as to convey the possibility of States implementing recreational activity in schools across Africa. The developmental focal benefits of dance education are fourfold and are enumerated and discussed individually below.

\subsection{Physical development}

The first development to be discussed here is the physical attribute of dance education, as it is one of the most visible benefits. Learners can acquire a great range of motion, coordination, muscular strength and stamina through dancing. Dance training creates movement sequences to build kinaesthetic memory on how to use the body to execute movements. These movements, which are made up of sequences, also help the child with his or her coordination skills. ${ }^{94}$ CAPS for Dance Studies goes on to add physical attributes such as core stability, flexibility, and neuromuscular skills to the list of physical developmental advantages of dance education. ${ }^{95}$ All these attributes collectively contribute to the physical wellbeing of the child, subsequently building the child's dance lexicon as the dance technique becomes more complex, enhancing his or her performance and creative skills. Creating time and space for dance activities at schools, then, allows children an opportunity to work on their health as well as physical aspect of their development.

\subsection{Cognitive development}

It is incontrovertible that skills such as creativity and critical thinking are a pertinent and central element of cognitive development. One of the aims of dance education is to promote the awareness of safe

92 Department of Basic Education of the Republic of South Africa 'Curriculum Assessment Policy Statement' (2011).

93 Department of Basic Education of the Republic of South Africa 'Curriculum Assessment Policy Statement' (2011) 8.

94 B White 'How Dance Classes Benefit Early Development' (2012) https:// www.dancetoevolve.com/blog/bid/207943/How-Dance-Classes-Benefit-EarlyDevelopment (accessed 27 April 2020).

95 Department of Basic Education of the Republic of South Africa 'Curriculum Assessment Policy Statement' (2011) 12. 
dance practices. Safe dance practices entail learning the purpose and importance of warming up the body before a dance class and doing a 'cool down' exercise after a dance class, or any physical activity. Warming up is a fundamental aspect of safe dance practice, which improves performance and reduces chances of injuries. ${ }^{96}$ It also fosters the basic knowledge of the body's anatomy, taking cognisance of how our bodies operate when dancing. ${ }^{97}$ These principles can be closely linked to the western dance teaching pedagogies which, while essential, are only a fraction of what dance education brings to the table of awareness, for they neglect the cosmology of African dances.

African dance pedagogies that are closely linked to cultural heritage dances and contain such complexities and uniqueness in their teaching methods that they cannot be thrust into a singular pedagogy. ${ }^{98}$ African dances should be considered as 'domains of epistemological, historical, contextual and ontological knowledge that reflects on the place, the people, location, and the experience'. 99 Therefore, dance education of children in Africa may have the added value of teaching about cultural history and heritage.

When learning about African dance cosmology in the dance classroom, learners will begin to unpack the significance of the dances, and the references made to nature, ${ }^{100}$ which could assist in critically analysing humankind's relationship to and with nature; as well as trigger thoughts about the intersectionality within the African context as the African child starts to take part in dances which were made for specific purposes. Learners could start to delve into the complexities of the politics of intersectionality within Africa, and as awareness is brought upon this, the child stands a chance to be moulded into a more diverse human being. This is not to say that this cannot be achieved in other schooling subjects. However, perhaps because of the nature of dance education, it will allow the learners more freedom to express their thoughts, ${ }^{101}$ and dance education could concurrently work with other subjects to expand on these thoughts to form an Intergraded Curriculum. ${ }^{102}$

96 See generally: E Quin et al Safe Dance Practice (2015).

97 Department of Basic Education of the Republic of South Africa 'Curriculum Assessment Policy Statement' (2011) 17.

98 Mabingo (n 66 above) at 13

99 Mabingo (n 66 above) at 225

100 For example, the 'Acogny technique', which was founded by Mama Germaine Acogny, was built based on her knowledge of most West African traditional dances, with an influence on dance forms. Most movements are inspired by nature, plants or animals and everyday African life. See http:// ecoledessables.org/en/germaine-acogny/technique/

101 UNCRC General Comment No 17 para 20.

102 T Barton 'Changing The Future For Teaching' 10 December 2019 https:// servelearn.co/blog/integrated-curriculum-changing-the-future-of-teaching/ (accessed 1 June 2020). 
There is a possible opportunity for dance to provide a better image for young girls whose bodies are more subjected to exploitation, thus, focusing on issues of the girl child, as suggested by the UNCRC. ${ }^{103}$ Dance education will assist the African child, both male and female, to see their bodies past the European standard of what they should be, but as tools of information and carriers of history. With this understanding, a better community of human beings can arise.

Lastly, dance studies assist the learners to be aware of the space in which they dance so as to ensure that it is conducive for the learners to dance in, and what it is they would have to wear or do in order to make the space dance appropriate (the consideration of hygienic and unhygienic spaces comes to mind); the understanding of good nutrition to better the learner's health. Again, all of these steps are taken in order to ensure that the learner is safe and dances in a safe and conducive environment. However, the skills learnt in the dance class, of awareness of surroundings, tasks at hand, planning, cleanliness, and so forth, are applicable in other subjects and to life in general.

In the context of mental development, it is important to note that the dance classroom also affords learners the chance to be creative. This opportunity to be creative comes with a chance to further develop problem-solving, decision-making, analysis, synthesis, and application of skills and knowledge obtained in and outside the classroom - both formally and informally. ${ }^{104}$ Within the dance classroom, these skills are used when learners need to figure out how to connect movements together to create a sequence. However, they too can be transposed to other subjects and areas of life. Essentially, dance education presents children with an opportunity to learn about piecing together information in order to formulate an end result. Improvisation is another tool which is used in dance to allow the pupils to navigate for themselves, and carry out tasks differently from what the textbook would require them to. With only guidelines or facilitation, children are able to explore possibilities with their mind's creation and possibly formulate different and unique ways of achieving the goal at hand. Therefore, dance education also equips children with the important skills of independent thinking, formulating projects for presentation and processing thoughts and information. In addition to building confidence, this also supports the argument that education, as contemplated in the African Children's Charter, should always make room for the child to learn some lessons independently. ${ }^{105}$

103 UNCRC General Comment No 17 para 16.

104 Department of Basic Education of the Republic of South Africa 'Curriculum Assessment Policy Statement' (2011) 31.

105 Gose (n 29 above) 113. 
Given that dance is an art form which is about moving the body and expressing oneself, it can also serve as a form of therapy. Through ambidextrous ability of dealing with both the body and the mind, it has the capacity of building a child's confidence and making him or her feel 'whole' again. ${ }^{106}$ Dance possesses the qualities to function as a stress reliever and reduce depression, because dance is fun. The mind and body experience also increases the blood supply to the brain, also increasing the temporal and prefrontal brain activity responsible for improving memory, multitasking, and attention ${ }^{107}$. With these qualities it could assist a child's mind to be calm, broaden and be free to take on other subjects that they have to conquer at school. A consideration of these positive gains of dance further reiterate and support the argument of why a pas de deux curriculum, which includes education and recreational activity, is beneficial for the child.

\subsection{Socio-emotional development}

The term 'socio-emotional development' has been defined as to include the child's 'experience, expression, and management of emotions and the ability to establish positive and rewarding relationships with others'. ${ }^{108}$ Good socio-emotional development has been listed as one of the ' $21^{\text {st }}$ century skills' which every learner should be equipped with and should have. ${ }^{109}$

This skill is listed as one of the $21^{\text {st }}$ century skills because being able to interact with your peers and colleagues is important, indispensable, in fact, in the $21^{\text {st }}$ century world people skills are essential for meaningful interactions and honing the ability to present yourself with confidence. Additionally, they are also necessary for leadership as they equip you with the tools to effectively lead while the right of others to be heard. To be able to attain this skill, a learner should be given the opportunity to tap into his or her interpersonal intelligence, which is the ability to understand and relate to others, as well as his or her intrapersonal Intelligence, which allows for introspection and the awareness of self. Recalling the need for education to have utility which lasts longer than a child's formal

106 P Alpert 'The Health Benefits of Dance' (2011) 23 Home Health Care Management \& Practice 155

107 Alpert (n 106 above) 155 - 156.

$108 \mathrm{~J}$ Cohen et al 'Helping Young Children Succeed: Strategies to Promote Early Childhood Social and Emotional Development' 12 February 2005 https://www. zerotothree.org/resources/136-helping-young-children-succeed-strategies-topromote-early-childhood-social-and-emotional-development (accessed 26 April 2020).

109 For a full discussion of the skills necessary for the $21^{\text {st }}$ century education, see generally: Centre for Curriculum Design Skills for the $21^{\text {st }}$ Century: What Should Students Learn 2015 https://curriculumredesign.org/wp-content/uploads/CCRSkills_FINAL_June2015.pdf. 
education career, placing a premium on the development of such areas for every child is no doubt in their best interests. Not only this, it is the obligation of every State Party to ensure that this development is allowed to occur within the setting of achieving the right to education.

In addition to its other benefits, it is also important to note that dance education can be used as a means to enhance the child's interpersonal skills and intrapersonal Intelligence. ${ }^{110}$ In the specific case of South Africa, Dance Studies, as contemplated in the CAPS curriculum, positively endorse educators to teach children people management skills and how to collaborate and work with one another. ${ }^{111}$ This curriculum places a premium on social interaction and holds that it is essential to learning, because we often learn best when working with others. When in partners or doing group work in the dance classroom, children can learn exercises by examining one another and by way of demonstrating to each other as well. While taking notes, and through feedback sessions facilitated by the teacher, the children can draw knowledge from each other. This will teach the child to be able to give constructive criticism and to receive constructive criticism. It will also teach the child self-discipline, knowing when it is their turn to speak and when they are required to listen and give chance to their peers.

One of the functions of dance in society is that it teaches leaners to be able to freely express themselves. One of the aims of South Africa's CAPS for dance studies is to develop the body as an instrument of expression. ${ }^{112}$ Through improvisation and choreography, children will be given a chance to share their political ideas and feelings towards certain issues; thus, also realising their right of freedom of expression. ${ }^{113}$ With the use of their body they will learn to interpret the emotions and intension behind what they are trying to communicate, which is another function of dance in society - this will be elaborated in the next topic area of cultural development.

\subsection{Cultural development}

Through dance, children will learn to engage with social, cultural, environmental, and community issues. ${ }^{114}$ In the dance classroom,

110 AG Gilbert 'Toward best practices in dance education through the theory of multiple intelligences' (2003) 3 Journal of Dance Education 32.

111 Department of Basic Education of the Republic of South Africa 'Curriculum Assessment Policy Statement' (2011) 31.

112 Department of Basic Education of the Republic of South Africa 'Curriculum Assessment Policy Statement' (2011) 8.

113 Gose (n 29 above) 136.

114 Department of Basic Education of the Republic of South Africa 'Curriculum Assessment Policy Statement' (2011) 8. 
they will be exposed to different dance styles, whether it be traditional dance or contemporary, or modern dance forms. The learners will learn about the basic developments of dances in the past and the present, unpacking the purpose they served then and now. For example, in South Africa's CAPS for dance studies curriculum, learners in the tenth and eleventh grade are required to learn an indigenous dance form. If the learners learn the Indlamu, ${ }^{115}$ they will learn about the culture of Zulu people, where Zulu people come from and where they are predominantly found on the map, the purposes of the dance then and now, and how it has shifted to accommodate the now. In turn, cultural traditions and heritage are being passed down from generation to generation, even within the classroom. Therefore, reinforcing and preserving the cultural identity and customs of the Zulu nation.

Zuma has documented an analysis of the importance of play, and song, by use of indigenous childhood games in the dance classroom. The function of indigenous childhood games was not only for physical and social-emotional development alone, but also a means to transmit information or life lessons. ${ }^{116}$ Because indigenous childhood games are community based, they would generally contain information of events that took place around the community. This again is another opportunity for cultural development in a classroom with pupils who come from different community and social backgrounds to exchange knowledge and teachings through play and song.

Considering all of these developmental benefits of dance education, then, it is argued that the pas de deux approach of observing both the right to education and the right to recreational activity at schools is both important as well as beneficial for the child, on numerous levels. Dance is not only a tool of entertainment, but it is also an interaction between the body and the mind. ${ }^{117}$ Through dance, or dance education, the African child has the opportunity to grow to be a physically strong human being, while actively practicing to lead a healthy lifestyle, which also includes a boosted psychological wellbeing of the African child. Not only will the physical contribute to the psychological wellbeing of the learner, but also the ability to have a space where they can obtain the knowledge on how to express themselves, which could be a therapeutic endeavour. Through the teachings and understanding of African dance cosmology, the African child could find solace in the understanding of their being, and their being in relation to the world; endorsement of their own culture and how other cultures may possibly intertwine and this could

115 Indlamu is a traditional dance performed by the Zulu people of South Africa.

116 See generally: Zuma (n 62 above).

117 AV Balgaonkar 'Effect of dance/motor therapy on the cognitive development of children' (2010) 3 International Journal of Art and Sciences 55. 
assist the African child to be more diverse in their thinking. The sharing of this knowledge with other peers in a proactive manner will be able to assist the African child with being able to communicate these thoughts through dance, and also be able to communicate and share ideas with others within the learning environment, and could assist with communicating with the community at large.

In essence, dance has holistic development, where the African child may not only obtain $50 \%$ of what they hear and see, or $70 \%$ of what they say and write, but $90 \%$ of what they learn and physically actualise. ${ }^{118}$ With these provisions made by the State Party, they would be doing a service to the African child in ensuring that they obtain a holistic development for the African child's betterment.

\section{The best interests of the child}

The best interests of the child must be considered whenever dealing with the child, no matter the context, consideration or action. This section thus tangentially discusses the principle, in order to show its importance and relevance to the main discussion. The best interests principle dictates that, whenever dealing with a child, one has to consider the child's best interest. Semantically, this discussion also brings attention to another difference between the African Children's Charter and the Convention on the Rights of the Child. ${ }^{119}$ The African Children's Charter states that 'in all actions concerning the child undertaken by any person or authority the best interests of the child shall be the primary consideration. ${ }^{120}$ It has been argued that, in relation to the protection of the best interests of the child, the African Children's Charter offers a stronger protection than its counterpart, the CRC. ${ }^{121}$ This is because the Charter makes the consideration of the best interests of the child the primary consideration, ${ }^{122}$ while the CRC makes it a primary consideration. ${ }^{123}$

The best interests of the child principle was first introduced in 1959.124 It was then later transposed into the CRC, which was designed for the purpose of protecting the best interests of the child. ${ }^{125}$ Similarly, by making the best interests of the child the primary consideration in all matters concerning the child, the African

118 Balgaonkar (n 117 above) 61.

119 Gose (n 29 above) 25 - 26.

120 African Children's Charter art 4(1).

121 Gose (n 29 above) 26; Lloyd (n 3 above) 13 - 14.

122 African Children's Charter art 4(1).

123 Convention on the Rights of the Child art 3(1).

124 Declaration of the Rights of the Child, Principle 2.

125 Kohm (n 10 above) 323. 
Children's Charter serves the same purpose. ${ }^{126}$ In fact, the African Committee of Experts, the guardians of children's rights in Africa, have confirmed in case law too that the best interests of the child must be observed in all matters pertaining to children. ${ }^{127}$

The best interests of the child principle can be broken down into three elements. Firstly, it is a 'rule of procedure', in terms of which all decision-making processes and decisions made in relation to children must consider the principle. ${ }^{128}$ Secondly, it is a 'function of a substantive right', in that it is a guarantee that the principle will be applied in all matters dealing with the child. ${ }^{129}$ Finally, it is a fundamental and interpretive 'legal principle', which, by design, implores adults to act in the best interests of the child. ${ }^{130}$

When applying these elements to the rights in focus, the test shows that the propositions made here, are in the best interests of the child. The UNCRC has stated that the right to education, naturally, is linked to the best interests of the child, ${ }^{131}$ as all decisions regarding the child's right to education must take account of the best interests principle. ${ }^{132}$ Furthermore, one of the aims of education is to provide the child with an education which is of good quality and mindful of the best interests principle. ${ }^{133}$ With regard to the right to recreational activity, the Committee has also stated categorically that the realisation of the rights under article 31 of the CRC, of which recreational activity is one, is 'by definition in the best interest of the child'. 134 Therefore, in the pas de deux education curriculum, the best interests of the child are observed as an independent principle as well as a central pillar in the realisation of other rights, particularly the rights of the child to education and recreational activity.

Essentially, noting the centrality and importance of the best interests of the child principle in the African Children's Charter, it is argued here that the propositions made above are in the best interest of the child. Both access to education as well as recreational activity

126 Institute for Human Rights and Development in Africa (IHRDA) and Open Society Justice Initiative (on behalf of Children of Nubian Descent in Kenya) $v$ The Government of Kenya, Decision No 002/Com/002/2009, African Committee of Experts on the Rights and Welfare of the Child (22 March 2011) para 29; Nyarko \& Ekefre (n 11 above) 388.

127 Michelo Hansungule and Others (on behalf of Children in Northern Uganda) v The Government of Uganda, Communication No $1 / 2015$ at the $21^{\text {st }}$ Ordinary Session, African Committee of Experts on the Rights and Welfare of the Child (15 - 19 April 2015) para 37.

$128 \mathrm{~J}$ Zermatten 'The Best Interests of the Child Principle: Literal Analysis and Function' (2010) 18 International Journal of Children's Rights 485.

129 As above.

130 As above.

131 UNCRC General Comment No 1 para 6.

132 UNCRC General Comment No 7 (2007) Implementing child rights in early childhood CRC/C/GC/7/Rev. 1 para 13.

133 UNCRC General Comment No 1 para 9.

134 UNCRC General Comment No 17 para 17. 
are in the best interest of the child, and they observe the best interests principle - meaning that all elements of the principle are realised. The developmental benefits attached to the realisation of both rights have an undeniably and positively high utility. Therefore, it is submitted that the education and recreational activity pas de deux should be implemented within curricula because of the fact that, over and above all the benefits listed above, it would be in the best interest of the child to do so.

\section{Conclusion}

The discussion in this article was centred around four arguments. Firstly, it was established that the African Children's Charter recognises and protects the right of the African child to receive an education as well as take part in recreational activity. Secondly, it was argued that State Parties would do well to include dance, as a form of recreational activity, in their school curricular because of its benefits for their development and wellbeing. When these two themes are considered together, it is made evident that the school setting is an opportune place to ensure the realisation of both of these rights for children across the continent. Additionally, tangentially but importantly, it was argued that the proposals made herein would be in the best interests of the child, if realised. Finally, and also importantly, where State Parties implement curricular which feature recreational activity syllabi, they will be realising two of their obligations in terms of the African Children's Charter simultaneously. 